\title{
Article \\ Histological Evaluation of Multisonic Technology for Debridement of Vital and Necrotic Pulp Tissues from Human Molar Teeth. An Observational Study
}

\author{
David E. Jaramillo $^{1, *}$ and Alberto R. Arriola ${ }^{2}$ \\ 1 Department of Endodontics, School of Dentistry, University of Texas Health Science Center at Houston, \\ Houston, TX 77054, USA \\ 2 Department of Endodontics, Universidad Autonoma de Guadalajara, Guadalajara 44100, Jalisco, Mexico; \\ alarriola@mail.uag.mx \\ * Correspondence: David.E.Jaramillo@uth.tmc.edu; Tel.: +1-713-486-4224
}

check for

updates

Citation: Jaramillo, D.E.; Arriola, A.R. Histological Evaluation of

Multisonic Technology for

Debridement of Vital and Necrotic

Pulp Tissues from Human Molar

Teeth. An Observational Study. Appl.

Sci. 2021, 11, 11002. https://doi.org/

10.3390/app112211002

Academic Editor: Gianluca

Gambarini

Received: 14 October 2021

Accepted: 18 November 2021

Published: 20 November 2021

Publisher's Note: MDPI stays neutral with regard to jurisdictional claims in published maps and institutional affiliations.

Copyright: (c) 2021 by the authors. Licensee MDPI, Basel, Switzerland. This article is an open access article distributed under the terms and conditions of the Creative Commons Attribution (CC BY) license (https:// creativecommons.org/licenses/by/ $4.0 /)$.

\begin{abstract}
Background: This study evaluated the efficacy of a multisonic technology for the debridement of vital and necrotic pulp tissues in freshly extracted human mandibular molar teeth. Methods: Twelve teeth with a diagnosis of symptomatic irreversible pulpitis (SIP) and twelve teeth with a diagnosis of pulp necrosis with symptomatic apical periodontitis (SAP) were extracted. The GentleWave ${ }^{\circledR}$ procedure was performed on 10 teeth from each group. Four non-treated teeth served as histologic controls. Histological consecutive $5 \mu \mathrm{m}$ sections were obtained from the apical, middle, and coronal portion of the canals. The canals were evaluated for the presence of pulpal debris and bacteria. Results: In nine out of the ten specimens with SIP, no pulpal debris was detected in any portion of the canals. In the necrotic pulp group, eight out of the ten specimens had no detectable pulpal debris in any portion of the canal spaces. No bacteria were detected in the main canals, isthmuses, or lateral canals, but were detected deep within the dentinal tubules in 10 specimens. Conclusions: This study demonstrated that the multisonic technology was effective at removing vital and necrotic pulp tissue as well as bacteria from the root canal system, including inaccessible areas.
\end{abstract}

Keywords: $\mathrm{NaOCl}$; EDTA; multisonication; root canal debridement

\section{Introduction}

The goal of root canal therapy is to remove inflamed and necrotic pulp tissue from the root canal system to prevent or treat apical periodontitis [1]. As shown in numerous studies, bacteria have an important role in the inflammatory process of pulpal and periapical disease [2,3]. Because of this association, managing endodontic disease consists of a combination of mechanical instrumentation and chemical irrigation to reduce the bacterial load [4] to levels compatible with the healing process.

Many techniques for cleaning and preparing root canals have been recommended, along with the use of chemical solutions for disinfection, tissue dissolution, and removal of the smear layer [5]. Sodium hypochlorite $(\mathrm{NaOCl})$ is commonly used in root canal therapy for disinfection and tissue dissolution $[6,7]$.

Ethylenediaminetetraacetic acid (EDTA) is recommended for removal of the inorganic portion or smear layer [6,8]. No technique, however, for cleaning, preparing, and disinfecting the root canal system has been shown to be completely effective in removing all vital or necrotic tissue [9-22].

The lack of complete cleaning can be attributed to several factors such as the anatomical complexity of the root canal system, the accumulation of debris, and inactivation of the irrigation solution in difficult to reach areas (isthmuses, lateral canals, and fins) [23], and to the absence of an appropriate delivery of the irrigation solutions [24]. Moreira et al. [25] 
discussed the anatomical variation of the teeth and mechanical preparation through a meta-analysis and concluded that neither ultrasonic irrigation nor conventional positive pressure techniques are 100\% effective. Paque et al. [13] and van der Vyver [26] reported side effects such as alteration of the original canal anatomy and instrument fracture. In addition, it has been demonstrated that the efficacy of irrigation is correlated with the penetration depth of the needle [24] and that the vapor lock phenomenon can decrease irrigation efficiency [27].

A system using multisonic technology has recently been introduced (GentleWave $\left.{ }^{\circledR}\right)$. The technology uses a combination of broad-spectrum acoustic energy, advanced fluid dynamics, and accelerated chemistry to debride and disinfect the root canal system with minimal instrumentation. The mechanism of action allows efficient delivery of energy to all anatomical areas of the root canal system, including difficult to reach areas such as isthmuses, fins, lateral canals, and anastomoses [28]. The GentleWave System consists of a console and a sterile single-use procedure instrument (PI). The console degasses the procedure fluids which helps prevent vapor lock and then dilutes the procedure fluids to the desired concentrations ( $3 \% \mathrm{NaOCl}$ and $8 \%$ EDTA). The technology allows use of lower concentrations of $\mathrm{NaOCl}$ and EDTA than traditional root canal therapy. In addition, the console delivers approximately $50 \mathrm{~mL}$ of procedure fluid per minute that ensures that fresh procedure fluid is continuously delivered to the root canal system which creates accelerated chemistry. When the high-pressure fluid jet flows through the procedure instrument, the jet of fluid interacts with the stationary fluid in the pulp chamber to generate a shear force which produces a cavitation cloud. The cavitation cloud consists of thousands of microbubbles which implode to create broad spectrum acoustic energy that travels into the root canal system. The degassed fluids also help prevent the damping of the acoustic energy as it moves through the root canal system. In addition, the fluid jet generates vortical flow which helps refresh the procedure fluids and produces negative pressure at the apices of the root canals which minimizes fluid extrusion [29]. The combination of broad-spectrum acoustic energy, advanced fluid dynamics, and accelerated chemistry leads to increased dissolution of organic matter, including pulp tissue and biofilm. Chan et al. [30] have reported on the effectiveness of multisonic technology in removing hard tissue debris, and others have evaluated gutta-percha and sealer removal using this system [31]. Other reports include the healing and post-operative outcome [32,33], apical extrusion of the irrigant solution [34], and biofilm removal [35]. To date, only one study [28] could be found that has evaluated the cleaning ability of this technology in posterior teeth.

The purpose of this study was to evaluate the efficacy of the multisonic technology in the debridement of the complex root canal system of human mandibular molar teeth independent of the pulpal and periapical diagnosis, by examining histologically the root canals for remaining pulp tissue and bacteria.

\section{Materials and Methods}

The Institutional Review Board approved the study HSC-DB-18-0844. Urgent Care Clinic patients requesting the extraction of symptomatic mandibular molar teeth, rather than accepting endodontic treatment, were asked to participate in the study and informed consent was obtained by the principal investigator (DEJ). The teeth were selected based on the pulpal and periapical diagnosis and anatomical similarities as well as the acceptability of the teeth for the multisonic technology procedure. Previously treated, cracked, or fractured teeth were not selected. A total of 24 teeth with the diagnosis of symptomatic irreversible pulpitis (SIP) $(\mathrm{N}=12$ teeth) and pulp necrosis with symptomatic apical periodontitis (SAP) $(\mathrm{N}=12$ teeth) were selected. Immediately after extraction, each tooth was placed in an individual test tube containing $20 \mathrm{~mL}$ of phosphate buffered solution (PBS), except for control group teeth that were placed immediately in a $10 \%$ buffered formalin solution. The average length of the roots was $11 \mathrm{~mm} \pm 1.7 \mathrm{~mm}$ and the curvature degree was $20.5^{\circ} \pm 10.5^{\circ}$ for all specimens [36]. 
Digital periapical radiographs (buccal and mesial views) were taken to evaluate the teeth for similarities in terms of root length, number of root canals, and root curvature, to ensure that the teeth had similar root canal anatomy.

All similar teeth were evaluated under the dental microscope (Global Inc., Saint Louis, $\mathrm{MO}, \mathrm{USA}$ ) to make sure that none had any root fractures. All clinical procedures were completed immediately after the teeth were extracted. After the evaluation of the teeth, the crown of each tooth was disinfected by rubbing the crown with wet $2 \times 2$ gauze impregnated with $6 \% \mathrm{NaOCl}$.

The access cavities were made with a high-speed handpiece with a sterile \# 2 round carbide bur (Brasseler, Savannah, GA, USA) under constant water spray. The root canal orifices were located with a DG-16 endodontic explorer (HY-Friedy, Chicago, IL, USA) and a \# $10 \mathrm{~K}$ file (Kerr, Brea, CA, USA) was used to explore the root canals and gain patency. Working length was established per manufacturer instructions (1.5 mm short of the apical foramen). The roots were completely covered with a thick layer of hot glue in the furcation area and around the roots to create a closed system which mimics the root when it is enclosed by the bone socket [27].

After initial instrumentation with \# 10 and \# $15 \mathrm{~K}$ hand files (Kerr, Brea, CA, USA), all the canals were enlarged using Vortex Blue (Dentsply, Tulsa, OK, USA) \# 15/04 and \# 20/04 as recommended by the manufacturer. Then, $1 \mathrm{~mL}$ of $3 \% \mathrm{NaOCl}$ was delivered inside the root canal using a $5 \mathrm{~mL}$ syringe with a $30 \mathrm{G}$ irrigation needle (Dentsply, Tulsa, OK, USA) after each file. After preparing the root canals, an occlusal platform was created using Sound Seal (Sonendo Inc., Laguna Hills, CA, USA) per the manufacturer's instructions. The occlusal platform was reaccessed using a \# 557 carbide bur (Brasseler, Savannah, GA, USA) to the cavosurface margin of the original endodontic access. Then, a depth gauge was used to measure the depth of the pulp chamber. The corresponding sealing cap to the depth gauge was then selected and attached to the procedure instrument (PI) per manufacturer instructions. The PI was placed on the platform (Figure 1), ensuring that the sealing cap was fully seated to create a sealed environment. Then, the foot pedal was depressed to start the procedure. A sealed platform on the tooth is essential to prevent entry of air into the tooth which could impede the propagation of the energy and fresh fluids into the canal system. The initial cycle is a leakage test with distilled water for $1 \mathrm{~min}$. The purpose is to verify a completely sealed environment between the tooth and the procedure instrument (PI) as well as to ensure the appropriate flow rate and optimize the procedure fluids. Next is a 4 min cycle of $3 \% \mathrm{NaOCl}$, a flush of distilled water for $30 \mathrm{~s}, 1.5 \mathrm{~min}$ of $8 \%$ EDTA, and a final rinse cycle of distilled water for $15 \mathrm{~s}$. In total, approximately $350 \mathrm{~mL}$ of procedure fluids was delivered to each tooth. Once the procedure was completed, the platform and hot glue were removed from the tooth with the help of Kelly forceps. Using a $5 \mathrm{~mL}$ syringe with a 30G irrigation needle (Dentsply, Tulsa, OK, USA), 10\% buffered formalin (Thermo Shandon Ltd., Cheshire, WA, USA) was injected directly inside the root canals and the tooth was placed immediately into a container with $10 \%$ buffered formalin for at least $48 \mathrm{~h}$ before the specimen was processed. All procedures were performed individually by the principal investigator. Numbers were used to identify the specimens: 1 to 10 for symptomatic irreversible pulpitis (SIP), 11-20 for necrotic pulp (SAP), and 21-24 for the histologic control groups.

\subsection{Histologic Control Group}

Two teeth from each test group (symptomatic irreversible pulpitis/SIP, necrotic pulp/SAP) were selected to be used as controls. Upon extraction, the teeth were immediately and individually fixed in $10 \%$ buffered formalin and submitted for histological processing. 


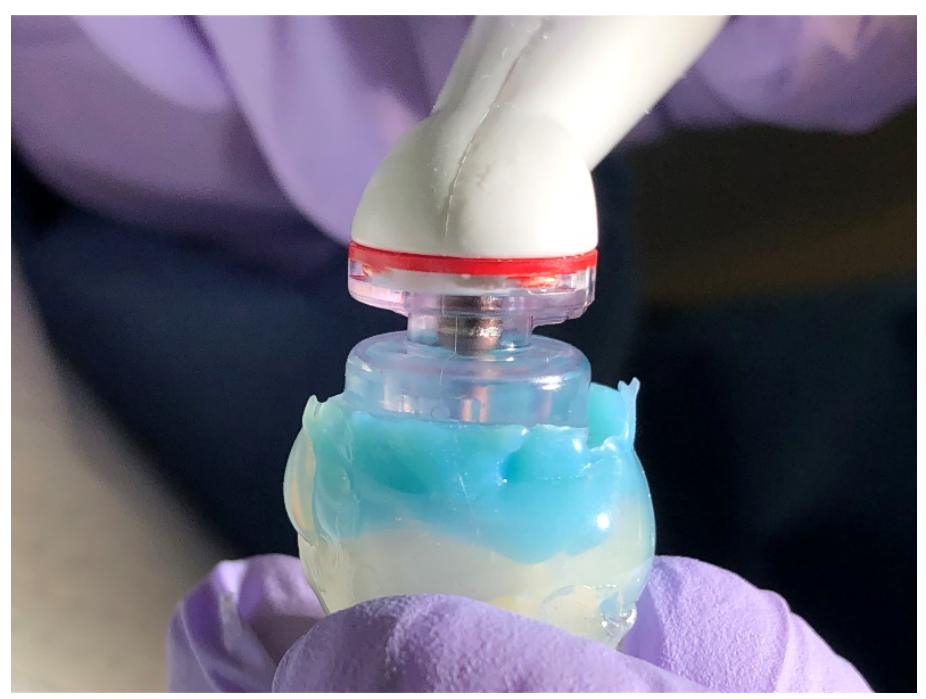

Figure 1. The corresponding sealing cap attached to the procedure instrument (PI) and positioned on the platform.

\subsection{Histological Process}

The Excelsior AS (Thermo Fisher Scientific Inc., Waltham, MA, USA) was used to process the tissues. Demineralization was carried out in an aqueous solution, which was a mixture of $22.5 \%$ (vol./vol) formic acid and $10 \%$ (wt/vol) sodium citrate for 3-4 weeks [37,38]. All specimens were washed with running tap water for $24-48 \mathrm{~h}$, followed by ascending grades of ethanol. The root segments were marked at $1 \mathrm{~mm}, 4 \mathrm{~mm}$, and $6 \mathrm{~mm}$ from the tip of the root and separated using a razor blade. Each portion of the root was individually embedded in paraffin for cross-sections. Twelve consecutive $5 \mu \mathrm{m}$ sections were obtained from the apical, middle, and coronal portion of the mesial and distal roots using a microtome (Leica RM 2235, Buffalo Grove, IL, USA). In the vital pulp tissue group (symptomatic irreversible pulpitis), all specimens were stained with hematoxylin-eosin (H\&E) to screen for the presence of pulp tissue remnants. In the pulp necrosis group (necrotic pulp/symptomatic apical periodontitis), 6 out of the 12 consecutive $5 \mu \mathrm{m}$ sections in each radicular third were stained with hematoxylin and eosin and 6 consecutive sections were stained using the Gram technique to detect Gram-negative and Gram-positive bacteria. The same procedure was used for the histologic control groups. Slides were examined under the BX41 light microscope using CellSens imaging software (Olympus Corp., Center Valley, PA, USA) by the principal investigator. All 12 consecutive cross-sections obtained from each radicular third were microphotographed and randomly ordered in a PowerPoint presentation for observation and grading by two blinded graders. Evaluations were performed separately. In case of disagreement between graders, they reviewed the findings until an agreement was reached [39].

In the vital group (symptomatic irreversible pulpitis), the specific characteristics analyzed were:

(a) Presence of pulp tissue and debris in the root canal lumen and fins.

(b) Presence of pulp tissue and debris inside isthmuses (if isthmus present).

(c) Presence of pulp tissue and debris inside lateral canals (if lateral canal present).

In the necrotic pulp group (symptomatic apical periodontitis), the specific characteristics analyzed in gram stain slides were the presence of bacteria:

(a) Adhered to necrotic pulp tissue located in the root canal lumen and fins.

(b) Adhered to necrotic pulp tissue located in the isthmuses (if isthmus present).

(c) Adhered to necrotic pulp tissue in lateral canals (if lateral canal present).

(d) Within dentinal tubules. 


\subsection{Statistical Analyses}

Using R statistical software [39], a generalized linear mixed effects model controlling for repeated measurements on individual teeth was performed to assess if differences in the amount of remaining pulp tissue and bacteria occurred in canals, isthmus, lateral canals, and dentinal tubules (for bacteria only).

\section{Results}

All consecutive histological sections in the histologic control groups stained with hematoxylin and eosin confirmed the presence of pulp tissue in the apical, middle, and coronal portions of the mesial and distal roots for both evaluated groups (Figure 2A,B). In addition, the Gram stain of the necrotic group showed the presence of bacteria in all portions of both roots as well as in the dentinal tubules near the canal walls (Figure 2C,D).
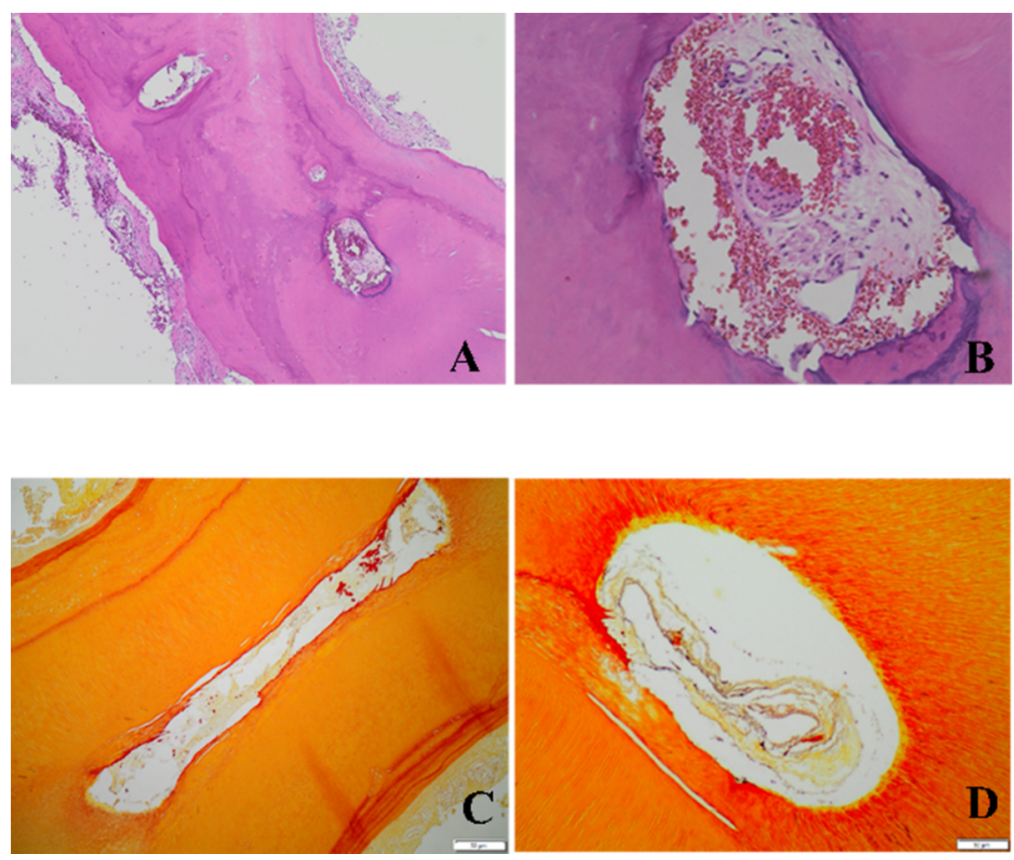

Figure 2. Photomicrographs of the histologic control groups. The hematoxylin and eosin technique was used to detect tissue and the Gram staining technique was used to detect the presence of bacteria. The photomicrographs show representative cross-sections of the vital controls (A, $4 \times$ and $\mathrm{B}, 20 \times)$ and the necrotic controls $(\mathbf{C}, 10 \times$ and $\mathbf{D}, 20 \times)$ in the apical region of mandibular molars.

Only three samples out of twenty treated teeth presented pulpal debris after the instrumentation and irrigation procedure-one from the symptomatic irreversible pulpitis (SIP) group and two from the necrotic symptomatic apical periodontitis (SAP) group (Tables 2 and 3).

Vital and symptomatic irreversible pulpitis (SIP) group: In nine out of ten specimens, no pulp tissue or debris was detected in the apical, middle, or coronal portion of the mesial and distal roots. This included two specimens with fused roots. Figure 3 shows an example of (3A) main canal and apical lateral canals and (3B) main canals and isthmus which are free of pulp debris. Figure $3 C, D$ show isthmuses and fins free of debris. In addition, Figure $3 \mathrm{E}, \mathrm{F}$ show that there is no debris in the uninstrumented portions of the root canal. 


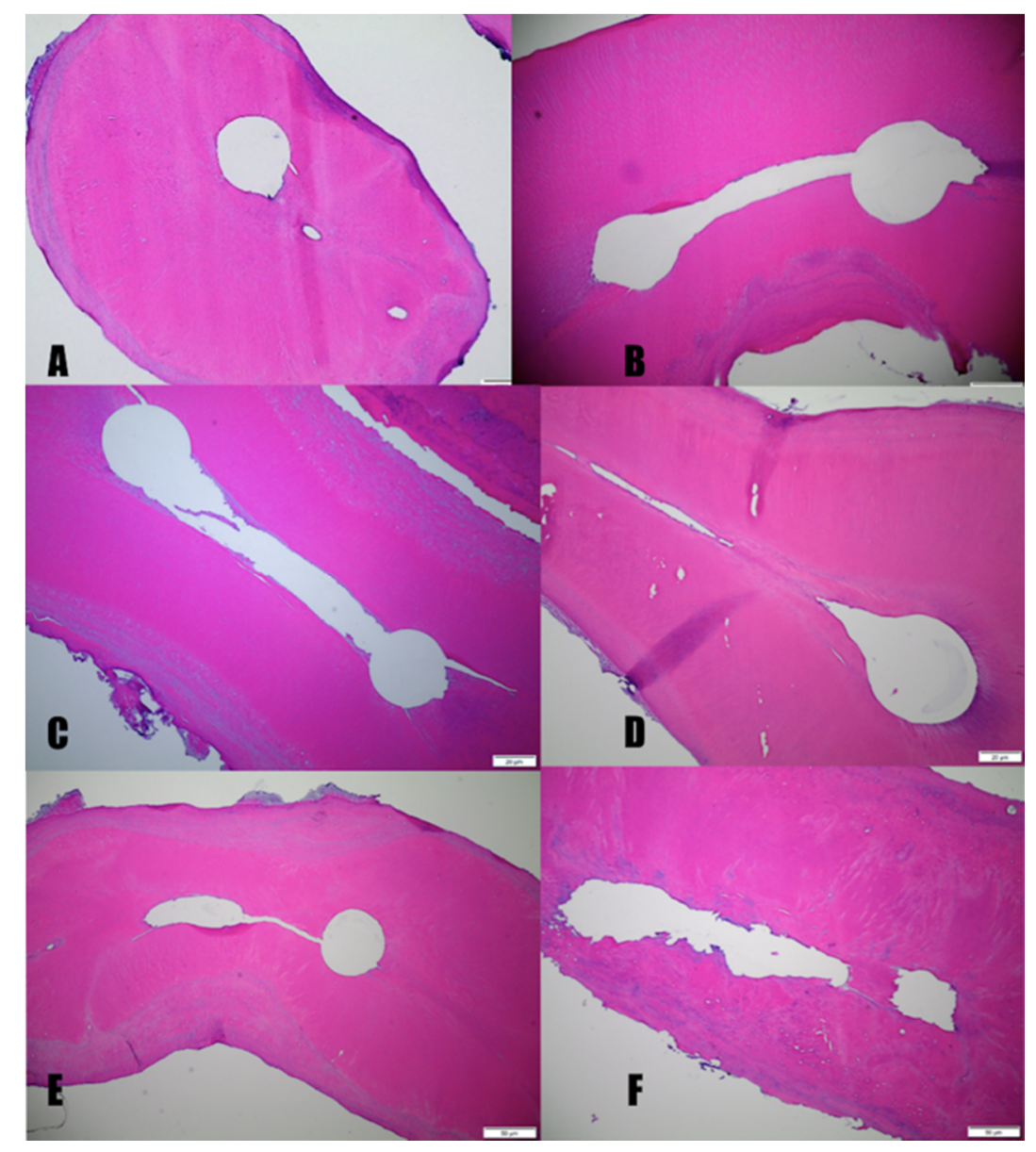

Figure 3. Photomicrographs of representative cross-sections from the vital mandibular molars group that have undergone H\&E staining. The apical regions of the mesial canals of vital mandibular molars show main canals and the difficult to reach areas including the isthmus and apical deltas free of pulpal debris. $(\mathbf{A}, 10 \times)$ and middle $(\mathbf{B}, 10 \times)$. The middle portion of the mesial-buccal (MB) and mesial lingual root canal shows the lack of pulpal debris in the isthmus and fins. (ML) $(\mathbf{C}, \mathbf{D}, 10 \times)$. E and $\mathbf{F}$ show the apical portion of a mesial root. Note in $(\mathbf{E}, 10 \times)$ the lack of pulp tissue or debris in the uninstrumented portion of the root canal and isthmus. $(F, 10 \times)$ shows the absence of pulp or tissue debris in completely uninstrumented canals as indicated by the irregularly shaped canal walls.

Pulp necrosis and symptomatic apical periodontitis (SAP) group: In eight out of ten specimens, no pulp debris was detected in the apical, middle, or coronal portion of the mesial and distal roots including the ramifications, isthmuses, or lateral canals. In two specimens, pulp debris was found in the apical portion of the mesial buccal root canal (Figure 4A,B). In ten out of ten specimens, no bacteria were detected in the main canals, isthmuses, or lateral canals of the mesial and distal roots. The apical portion of distal root shows complete pulpal debridement of the main and lateral canal (Figure 4C,D). Some bacteria were found deep in the dentinal tubules in all coronal sections of 10 specimens (Figure 4E,F). Table 1 shows the mean percentage of bacteria remaining deep within the dentinal tubules in the apical, middle, and coronal portions of the root canals. 


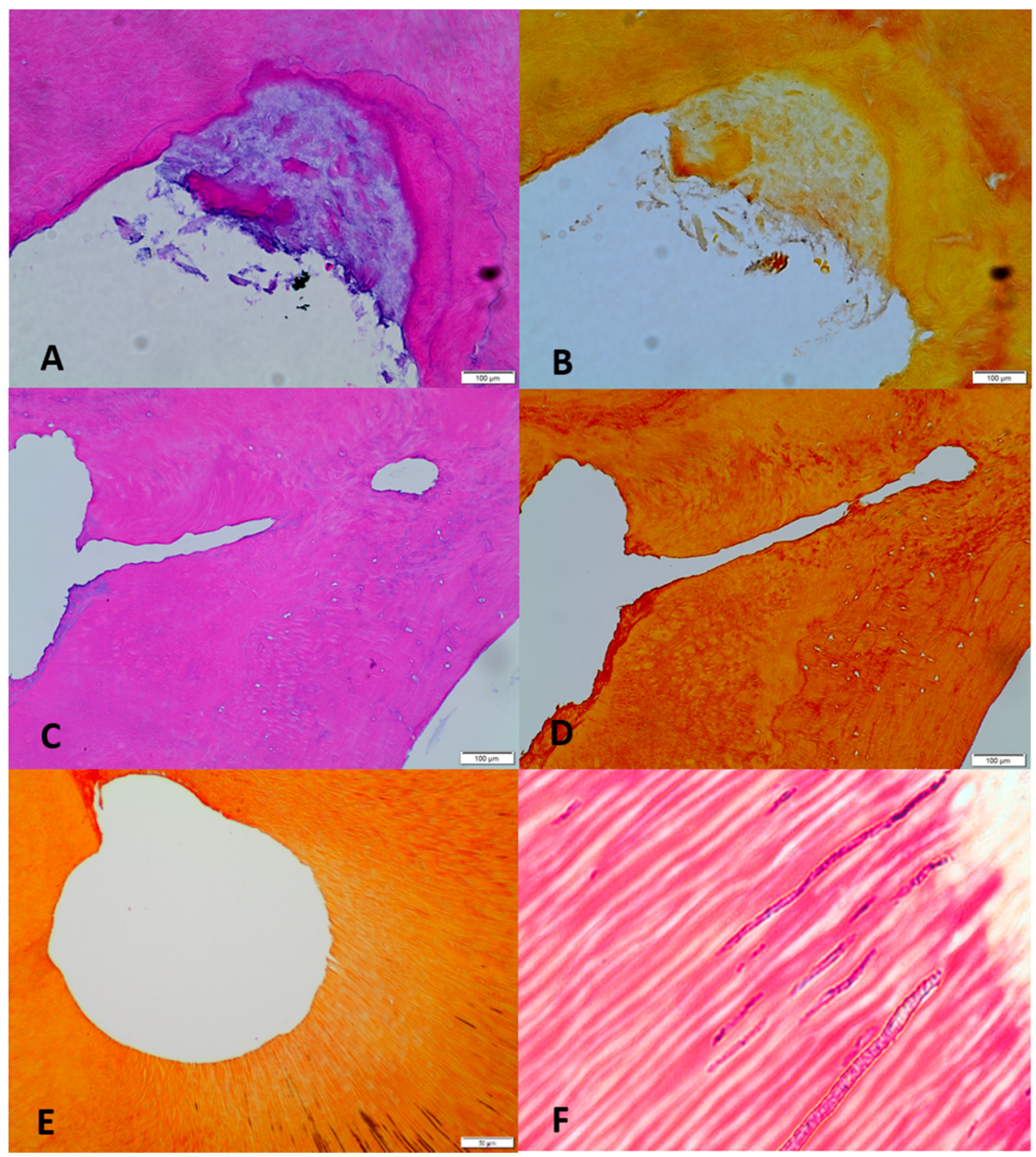

Figure 4. Photomicrographs of representative cross-sections from the pulp necrosis mandibular molars group. (A) $(20 \times, \mathrm{H} \& \mathrm{E})$ : The apical regions of the mesial buccal canal show debris accumulation at a root canal irregularity (fin). (B) $(20 \times$, Gram): No bacteria can be detected. (C) $(\mathrm{H} \& \mathrm{E}, 10 \times)$ : Apical section of distal root shows the complete debridement of main and lateral canal. (D) (Gram, $10 \times)$ : No bacteria can be detected. (E) $(\mathrm{H} \& \mathrm{E}, 20 \times)$ : Coronal section of mesial lingual root canal shows complete debridement of main canal. (F) (Gram, 100×): Presence of bacteria deep within dentinal tubules.

Table 1. Mean percentage of samples with bacteria inside the dentinal tubules.

\begin{tabular}{cccccc}
\hline & Root Canal & DB & DL & MB & ML $^{*}$ \\
\hline Portion & Coronal & 4.98 & 1.66 & 4.98 & 5.81 \\
& Mid & 3.32 & 0.00 & 2.49 & 3.32 \\
& Apical & 2.49 & 0.83 & 3.32 & 1.66 \\
\hline
\end{tabular}

* DB (distal buccal), DL (distal lingual), MB (mesial buccal), ML (mesial lingual).

Statistical analysis: Table 2 shows the analysis of deviance table for the generalized linear mixed effect model (GLMM) for the fixed effects of group (vital, necrotic), zone (coronal, mid, apical), and location (MB, ML, DB, DL root canal) on percent of teeth with pulp tissue remnants. The repeated measure effects of multiple cross-sections for each individual tooth were included as a random effect in the GLMM. Table 3 shows the analysis of deviance table for generalized linear mixed effect model (GLMM) for the fixed effects of group (vital, necrotic), zone (coronal, mid, apical), and location (isthmuses) on percent of 
teeth with pulp tissue remnants. The repeated measure effects of multiple cross-sections for each individual tooth were included as a random effect in the GLMM. Statistical analyses show that no differences could be detected among the groups (vital or necrotic), zones, remaining pulp tissue, or bacteria in the root canal systems.

Table 2. Analysis of deviance table for the generalized linear mixed effect model on percentage of teeth with pulp tissue remnants.

\begin{tabular}{ccccl}
\hline PULP & F & Df & Df. Res & Pr $(>$ F $)$ \\
\hline Group & 0.0134 & 1 & 18.295 & 0.9090 \\
\hline Zone & 1.7792 & 2 & 152.262 & 0.1723 \\
\hline Location & 1.5550 & 3 & 156.963 & 0.2024 \\
\hline Group: zone & 0.3139 & 2 & 152.029 & 0.7310 \\
\hline Group: location & 1.0298 & 3 & 155.209 & 0.3811 \\
\hline Zone: location & 0.1182 & 6 & 153.266 & 0.9941 \\
\hline Group: Zone: Location & 0.4476 & 4 & 152.029 & 0.7740 \\
\hline
\end{tabular}

$\overline{\mathrm{F} \text { (value of the F distribution), Df (degrees of freedom), Df. Res (residual (or error denomination)), } \operatorname{Pr}(>\mathrm{F})(p \text {-value }}$ probability of getting value $>$ F).

Table 3. Analysis of deviance table for generalized linear mixed effect model (GLMM) for the fixed effects of group (vital, necrotic), zone (coronal, mid, apical), and location (isthmuses) on percent of teeth with pulp tissue remnants.

\begin{tabular}{ccccl}
\hline ISTHMUS & F & Df & Df. Res & Pr $(>$ F $)$ \\
\hline Group & 0.1534 & 1 & 17.051 & 0.70015 \\
\hline Zone & 0.8005 & 2 & 110.061 & 0.45169 \\
\hline Location & 0.8315 & 3 & 116.571 & 0.47016 \\
\hline Group: zone & 2.5244 & 2 & 110.005 & 0.08474 \\
\hline Group: location & 1.9472 & 3 & 116.889 & 0.12582 \\
\hline Zone: location & 0.6081 & 6 & 110.609 & 0.72334 \\
\hline Group: Zone: Location & 0.6544 & 6 & 110.825 & 0.68646 \\
\hline
\end{tabular}

$\overline{\mathrm{F}}(\mathrm{F}$ distribution value), Df (degrees of freedom), Df. Res (residual (or error denomination)), $\operatorname{Pr}(>\mathrm{F})(p$-value probability of getting value $>$ F).

\section{Discussion}

The efficacy of root canal debridement using the multisonic technology was evaluated in this study. This technology uses broad spectrum acoustic energy, advanced fluid dynamics, and accelerated chemistry to debride and disinfect the entire complex root canal system with minimal instrumentation [34,40].

The ability to debride the root canal will depend on the pathological status of the pulp and the location of the pulp tissue within the root canal system. Vital teeth have vital pulp tissue that is very difficult to remove; while necrotic teeth have a combination of vital and necrotic tissue that can be easier to remove. Necrotic teeth also have bacteria in the main and lateral canals which can be very difficult to remove completely.

The apical portion of the root is the most challenging area to clean. It has already been demonstrated that rotary or hand instrumentation performs differently in each zone of the root. Thus, the ability of the multisonic technology to efficiently debride different pulp tissues and different areas of the root was assessed.

Several ex vivo, in vitro, and in vivo studies with various conventional instrumentation and irrigation techniques have shown that pulp tissue and bacteria may remain in complex root canal systems [41-44]. In addition, no difference between hand and rotary instrumentation in the cleaning and disinfection of the root canal system has been 
reported. The use of chemical solutions appears to be important and helps in the root canal debridement. This points out the limitation of mechanical instrumentation [45-52].

Tissue dissolution with $\mathrm{NaOCl}$ can be improved when the solution is activated, the time of exposure is extended, and the temperature is increased [53]. According to some authors [54-56], mechanical agitation, as well as fluid flow, can enhance the dissolving capacity of vital and necrotic pulp tissue by $\mathrm{NaOCl}$. Even though this project did not evaluate the conventional irrigation needle technique, the clear differences between the needle technique and the multisonic technology make the comparison difficult. These differences include: (1) the volume of the solution used is very different between the multisonic technology $(350 \mathrm{~mL}$ ) and conventional irrigation (39 mL [57]); (2) the conventional technique uses intermittent irrigation while the multisonic technology uses continuous refreshing of fluids for $6.5 \mathrm{~min}$; and (3) conventional irrigation uses laminar fluid flow in which the multisonic technology uses a combination of vortical flow and broad-spectrum acoustic energy. These differences may explain the multisonic technology's ability to better dissolve pulp tissue as well as remove bacteria.

Moreira et al. [25] performed a meta-analysis comparing passive ultrasonic irrigation to conventional irrigation techniques. The study demonstrated that there is no statistically significant difference in the presence of bacteria between the two techniques and there is bacteria remaining in the root canal system. Using histological evaluation of cleaning with ultrasonic irrigation, Gutarts et al. [58] showed that ultrasonic irrigation for $1 \mathrm{~min}$ in each canal after hand/rotary instrumentation cleaned the canals well 1-3 $\mathrm{mm}$ from the apex but the results for the isthmus region were not consistent over the same range. Varela et al. [59] showed that ultrasonic irrigation and hand irrigation removed more pulp debris from round-shaped canals compared to oval-shaped canals. This study shows that the multisonic technology with minimal instrumentation of 20/04 is sufficient to remove pulp tissue and disinfect the main canal, isthmuses, and lateral canals at all levels regardless of the shape of the canal. This finding is consistent with a previous study using the same technology where non-instrumented premolars were evaluated with scanning electron microscopy and it was demonstrated that predentin and tissue were removed [40]. In addition, Molina et al. [28] histologically evaluated mandibular and maxillary molars that were instrumented to 15/04 and they found the canals free of pulp tissue in $97.2 \%$ of mesial roots and $96.52 \%$ in the distal root. This study's results are consistent with the Molina study.

Root canal anatomy and root curvature are of main importance in the efficacy of ultrasonic irrigation. Castelo-Baz [60] compared passive ultrasonic irrigation (PUI) and continuous ultrasonic irrigation (CUI) in an artificial model. CUI had better results but had several disadvantages, including extrusion of irrigants beyond the root canal which compromises the safety of the technique and the possibility of creating a ledge if the irrigation needle is positioned beyond the root canal curvature. With the multisonication technology of the GentleWave System, the irrigation solution is able to reach the total length of the root canal with less likelihood of the solution being extruded into the periapical tissues due to negative apical pressure $[29,61]$. The degassed solutions used in the GentleWave system could eliminate vapor lock from the apical portion of the root canal system, when compared to sonic and ultrasonic [61]. De Gregorio et al. [62] found that apical negative pressure (ANP) was the only technique able to deliver the irrigation solution to the full working length, while passive ultrasonic irrigation (PUI) was able to reach lateral canals but was unable to break vapor lock. In a histological study in mesial roots of lower molars, Susin et al. [20] compared the efficacy of apical negative pressure (ANP) and manual dynamic irrigation (MDI) in the removal of debris from the isthmus area. The findings were similar in both groups with slightly better removal using ANP, especially in narrower isthmuses. Haapasalo [63] demonstrated better tissue dissolution obtained by GentleWave when compared to the same amount of $\mathrm{NaOCl}$ delivered by a size $19 \mathrm{G}$ needle attached to a syringe in a $5 \mathrm{~min}$ period. The technology uses degassed fluids which improves the implosive effect of the cavitation since the entrained air in non-degassed solutions can 
cause damping of acoustic and hydrodynamic energy [64]. Thus, the degassed fluid allows the energy generated by multiple wavelengths of sound in a broad range of frequencies to be more efficiently delivered throughout the root canal system (main canal, fins, isthmuses, lateral canal, etc.). The constant refreshing of $\mathrm{NaOCl}$ ensures a more effective breakdown and removal of tissue, bacteria, and biofilm [35].

The console pressurizes and delivers the fluids into the procedure instrument (PI). When the PI is placed in position, $1 \mathrm{~mm}$ above the pulp chamber floor, the irrigation solution flows at a high speed (9000 PSI). Inside the procedure instrument there is an orifice that turns the pressurized fluid into a high-speed stream of fluid. The stream of fluid interacts with the accumulated fluid inside the chamber, causing continuous hydrodynamic cavitation. The stream of fluid is deflected to generate vortical fluid dynamics and negative pressure. The implosion of bubbles inside the cavitation cloud generates shock waves and acoustic energy that propagate throughout the root canal system [64]. Charara et al. [34] demonstrated that the technology minimizes the possibility of extrusion of the treatment fluids.

Our findings showed the minimal presence of remaining bacteria within dentinal tubules. The importance of the chemical disinfection of the root canal system in in vitro models has been previously described $[4,65]$. It is recognized that bacteria inside dentinal tubules can be associated with persistent periapical disease [66,67]. Even though histological sections demonstrated cleaning of the root canal system, bacteria remained within the dentinal tubules. Caputa et al. [68] did not find strong evidence to formulate a clinical recommendation on the disinfection and healing effect of apical periodontitis in teeth with multiple root canals when ultrasonic irrigation was applied during primary root canal treatment. Future studies need to evaluate the ability of the multisonic technology to decontaminate the root canal space using microbiological methods.

One of the limitations of the present study is the lack of control groups with conventional irrigation technique. This study was designed as an observational study to understand the compatibilities of the multisonic technology and to verify that the correct protocols and procedures were used. Based on this study, an in vivo study with extraction was designed to compare the GentleWave procedure to the conventional irrigation and instrumentation technique.

\section{Conclusions}

In summary, numerous studies have shown the difficulty of adequately cleaning the root canal system independent of the instrumentation or irrigation technique used. In this study which used histological examination, the multisonic technology combined with minimal instrumentation was effective for removal of vital and necrotic pulp tissue from the root canal system and inaccessible areas. Future studies are needed to compare the multisonic technology to other techniques and technologies. In addition, in vivo studies should be conducted to evaluate the long-term prognosis of this minimally invasive technology.

Author Contributions: D.E.J. designed and conducted the research project; presented consent form to patients, made teeth selection, performed GentleWave procedure; reviewed and photographed all histological sections; reviewed literature and select references and edited the manuscript. A.R.A. co-designed the study, reviewed histological sections, selected literature, and helped in the conceptualization of the manuscript. All authors have read and agreed to the published version of the manuscript.

Funding: A grant provided by Sonendo Inc. supported the study.

Institutional Review Board Statement: The University of Texas Health Science Center at Houston RCOI reviewed and approved Management Plan (HSC-DB-18-0844).

Informed Consent Statement: Written informed consent has been obtained from the patient(s) to publish this paper. 
Data Availability Statement: R Core Team (2017). R: A language and environment for statistical computing. R Foundation for Statistical Computing, Vienna, Austria. URL https:/ /www.Rproject. org/ (accessed on 9 November 2019).

Acknowledgments: Special thanks to: Timothy Kirkpatrick and Renato Silva for performing the evaluation of the histological sections. Ransome van der Hoeven, for his laboratory contribution and CD Johnson for Urgent Care Clinic assistance. Candy Bales for performing the histological process at the UTH Health SOD Pathology laboratory, Julian N. Holland III for the statistical analysis, and Leif K. Bakland for his help in the editing of the manuscript.

Conflicts of Interest: David E. Jaramillo "has research-related financial interest in Sonendo". Jaramillo had no direct access to research account money. Alberto R. Arriola declares "no potential conflict of interest relevant to this article".

\section{References}

1. Ng, Y.-L.; Mann, V.; Gulabivala, K. Outcome of primary root canal treatment: A systematic review of the literature. Int. Endod. J. 2007, 40, 921-939. [CrossRef]

2. Miller, W.D. Microorganisms of the human mouth. Dent. Cosm. 1891, 9, 689-713. [CrossRef]

3. Sundqvist, G. Bacteriological Studies of Necrotic Pulps. Ph.D. Thesis, University of Umea, Umea, Sweden, 1976.

4. Ørstavik, D.; Haapasalo, M. Disinfection by endodontic irrigants and dressings of experimentally infected dentinal tubules. Endod. Dent. Traumatol. 1990, 6, 142-149. [CrossRef] [PubMed]

5. Jou, Y.T.; Karabucak, B.; Levin, J.; Liu, D. Endodontic working width: Current concepts and techniques. Dent. Clin. N. Am. 2004, 48, 323-335. [CrossRef]

6. Torabinejad, M.; Handysides, R.A.; Khademi, A.A.; Bakland, L.K. Clinical implications of the smear layer in endodontics: A review. Oral Surg. Oral Med. Oral Pathol. Oral Rad. Endodontology 2002, 94, 658-666. [CrossRef] [PubMed]

7. Zehnder, M.; Kosicki, D.; Luder, H.; Sener, B.; Waltimo, T. Tissue-dissolving capacity and antibacterial effect of buffered and unbuffered hypochlorite solutions. Oral Surg. Oral Med. Oral Pathol. Oral Rad. Endodontology 2002, 94, 756-762. [CrossRef] [PubMed]

8. Peters, O.A.; Noblett, W.C. Endodontics: Principles and Practice: Cleaning and Shaping, 5th ed.; Saunders: Philadelphia, PA, USA, 2015; pp. 273-300.

9. Gutiérrez, J.H.; Garcia, J. Microscopic and macroscopic investigation on results of mechanical preparation of root canals. Oral Surg. Oral Med. Oral Pathol. 1968, 25, 108-116. [CrossRef]

10. Langeland, K.; Liao, K.; Pascon, E.A. Work-saving devices in endodontics: Efficacy of sonic and ultrasonic techniques. J. Endod. 1985, 11, 499-510. [CrossRef]

11. Walker, T.L.; del Rio, C.E. Histological evaluation of ultrasonic and sonic instrumentation of curved root canals. J. Endod. 1989, 15, 49-59. [CrossRef]

12. Peters, O.A.; Schönonberger, K.; Laib, A. Effects of four Ni-Ti preparation techniques on root canal geometry assessed by micro computed tomography. Int. Endod. J. 2001, 34, 221-230. [CrossRef]

13. Paque, F.; Lalb, A.; Gautschi, H.; Zehnder, M. Hard-tissue debris accumulation analysis by high resolution computed tomography scans. J. Endod. 2009, 35, 1044-1047. [CrossRef]

14. Forghani, M.; Afshari, E.; Parisay, I.; Garajian, R. Effect of a passive sonic irrigation system on elimination of Enterococcus Faecalis from root canal system of primary teeth, using different concentrations of sodium Hypochlorite: An in vitro evaluation. J. Dent. Res. Dent. Clin. Dent. Prospect. 2017, 11, 177-182. [CrossRef]

15. Kaloustian, M.K.; Nehme, W.; El Hachem, C.; Zogheib, C.; Ghosn, N.; Mallet, J.P.; Diemer, F.; Naam, A. Evaluation of two shaping system and two sonic irrigation devices in removing root canal filling material from distal roots of mandibular molars assessed by micro CT. Int. Endod. J. 2019, 52, 1635-1644. [CrossRef]

16. Van der Sluis, L.W.; Versluis, M.; Wu, M.K.; Wesselink, P.R. Passive ultrasonic irrigation of the root canal: A review of the literature. Int. Endod. J. 2007, 40, 415-426. [CrossRef] [PubMed]

17. Beus, C.; Safavi, K.; Stratton, J.; Kaufman, B. Comparison of the effect of two endodontic irrigation protocols on the elimination of bacteria from root canal system: A prospective, randomized clinical trial. J. Endod. 2012, 38, 1479-1483. [CrossRef]

18. Divito, E.; Peters, O.A.; Olivi, G. Effectiveness of the erbium; YAG laser and new design radial and stripped tips in removing the smear layer after root canal instrumentation. Lasers Med. Sci. 2012, 27, 273-280. [CrossRef] [PubMed]

19. Ordinola-Zapata, R.; Bramante, C.M.; Aprecio, R.M.; Handysides, R.; Jaramillo, D.E. Biofilm removal by $6 \%$ sodium hypochlorite activate by different irrigation techniques. Int. Endod. J. 2014, 47, 659-666. [CrossRef] [PubMed]

20. Susin, L.; Liu, Y.; Yoon, C.; Parente, J.M.; Loushine, R.J.; Ricucci, D.; Bryan, T.; Weller, R.N.; Pashley, D.H.; Tay, F.R. Canal and isthmus debridement efficacies of two irrigant agitation techniques in a close system. Int. Endod. J. 2012, 43, 1077-1090. [CrossRef]

21. Pawar, R.; Algaied, A.; Safavi, K.; Boyko, J.; Kaufman, B. Influence of an apical negative pressure irrigation system on bacterial elimination during Endodontic Therapy; A prospective randomized clinical study. J. Endod. 2012, 38, 1177-1181. [CrossRef] 
22. Mancini, M.; Cerroni, L.; Iorio, L.; Armellin, E.; Conte, G.; Cianconi, L. Smear layer removal and canal cleanliness using different irrigation systems (Endo Activator, EndoVac and Passive Ultrasonic Irrigation): Field emission scanning electron microscopic evaluation in an in-vitro study. J. Endod. 2013, 39, 1456-1460. [CrossRef]

23. De-Deus, G.; Reis, C.; Beznos, D.; de Abranches, A.M.G.; Coutinho-Filho, T.; Paciornik, S. Limited ability of three commonly used thermo-plasticized gutta-percha techniques in filling oval-shaped canals. J. Endod. 2008, 34, 1401-1405. [CrossRef]

24. Boutsioukis, C.; Lambrianidis, T.; Verhaagen, B.; Versluis, M.; Kastrinakis, E.; Wesselink, P.R.; van der Sluis, L.W.M. The effect of needle-insertion depth on the irrigant flow in the root canal: Evaluation using and unsteady computational fluid dynamics model. J. Endod. 2010, 36, 1664-1668. [CrossRef] [PubMed]

25. Moreira, R.N.; Pinto, E.B.; Galo, R.; Falci, S.G.M.; Mesquita, A.T. Passive ultrasonic irrigation in the root canal: Systematic review and meta-analysis. Acta Odontol. Scand. 2019, 77, 55-60. [CrossRef]

26. Van der Vyver, P.J.; Paleker, F.; Vorster, M.; de Wet, F.A. Root canal shaping using nickel titanium M-wire, and Gold Wire: A micro-computed tomographic comparative study of One Shape, Pro Taper Next, and Wave One Gold instruments in Maxillary First molars. J. Endod. 2019, 45, 62-67. [CrossRef]

27. Tay, F.R.; Gu, L.S.; Schoeffel, G.J.; Wimmer, C.; Susin, L.; Zhang, K.; Arun, S.N.; Kim, J.; Looney, S.W.; Pashley, D.H. Effect of Vapor lock on the root canal debridement by using a side-vented needle for positive-pressure irrigant delivery. J. Endod. 2010, 36, 745-750. [CrossRef]

28. Molina, B.; Glickman, G.; Vandrangi, P.; Khakpour, M. Evaluation of root canal debridement of human molars using the GentleWave system. J. Endod. 2015, 41, 1701-1705. [CrossRef]

29. Haapasalo, M.; Shen, Y.; Wang, Z.; Park, E.; Curtis, A.; Patel, P.; Vandrangi, P. Apical pressure created during irrigation with the GentleWave system compared to conventional syringe irrigation. Clin. Oral Investig. 2015, 20, 1525-1534. [CrossRef] [PubMed]

30. Chan, R.; Versiani, M.A.; Friedman, S.; Malkhassian, G.; Sousa-Neto, M.D. Leoni, G.B.; Silva-Souza, Y.T.C.; Basrani, B. Efficacy of 3 Supplementary irrigation protocols in the removal of hard tissue debris from the mesial root canal system of mandibular molars. J. Endod. 2019, 45, 923-929. [CrossRef]

31. Wright, C.R.; Glickman, G.N.; Jalali, P.; Umorin, M. Effectiveness of gutta-percha/sealer removal during retreatment of extracted human molars using the GentleWave system. J. Endod. 2019, 45, 808-812. [CrossRef]

32. Sigurdsson, A.; Le, K.T.; Woo, S.M.; Rassoulian, S.A.; McLachlan, K.; Abbassi, F.; Garland, R.W. Six-months healing success rates after endodontic treatment using the novel GentleWave system: The pure prospective multi-center clinical study. J. Clin. Exp. Dent. 2016, 8, 290-298. [CrossRef] [PubMed]

33. Grigsby, D.; Ordinola-Zapata, R.; McClanahan, S.B.; Fok, A. Postoperative pain after treatment using GentleWave system: A randomized controlled trial. J. Endod. 2020, 46, 1017-1022. [CrossRef]

34. Charara, K.; Friedman, S.; Sherman, A.; Kishen, A.; Malkhassian, G.; Khakpour, M.; Basrani, B. Assessment of apical extrusion during root canal irrigation with a novel GentleWave system in a simulated apical environment. J. Endod. 2016, 42, 135-139. [CrossRef] [PubMed]

35. Choi, H.W.; Park, S.Y.; Kang, M.K.; Shon, W.J. Comparative analysis of biofilm removal efficacy by multisonic ultracleaning system and passive ultrasonic activation. Materials 2019, 21, 3492. [CrossRef] [PubMed]

36. Schneider, S.W. A comparison of canal preparations in straight and curved root canals. Oral Surg. Oral Med. Oral Pathol. 1971, 32, 271-275. [CrossRef]

37. Ricucci, D.; Siqueira, J.F., Jr.; Bate, A.L.; Ford, T.R.P. Histologic Investigation of the Root Canal-treated Teeth with Apical Periodontitis: A Retrospective Study from Twenty- four Patients. J. Endod. 2009, 35, 493-502. [CrossRef]

38. Ricucci, D.; Loghin, S.; Siqueira, J.F., Jr. Correlation between clinical and histologic pulp diagnoses. J. Endod. 2014, 40, 1932-1939. [CrossRef]

39. R Core Team. R: A Language And Environment For Statistical Computing; R Foundation for Statistical Computing: Vienna, Austria, 2017. Available online: https:/ / www.Rproject.org/ (accessed on 9 November 2019).

40. Wang, Z.; Shen, Y.; Haapasalo, M. Root canal wall dentin structure in uninstrumented but cleaned human premolars: A scanning electron microscopic study. J. Endod. 2018, 44, 842-848. [CrossRef]

41. Nair, P.N.; Henry, S.; Cano, V.; Vera, J. Microbial status of apical root canal system of human mandibular first molars with primary apical periodontitis after "one-visit" endodontic treatment. Oral Surg. Oral Med. Oral Pathol. Oral Radiol. Endod. 2005, 99, 231-252. [CrossRef]

42. Arya, A.; Bali, D.; Grewal, M.S. Histological analysis of cleaning efficacy of hand and rotary instruments in the apical third of the root canal: A comparative Study. J. Conserv. Dent. 2011, 14, 237-240. [CrossRef]

43. Vera, J.; Siqueira, J.F., Jr.; Ricucci, D.; Loghin, S.; Fernandez, N.; Flores, B.; Cruz, A.G. One-versus two-visit endodontic treatment of teeth with apical periodontitis: A histobacteriologic study. J. Endod. 2012, 38, 1040-1052. [CrossRef]

44. Perez, A.R.; Ricucci, D.; Vieira, G.C.S.; Provenzano, J.C.; Alves, F.R.; Marceliano-Alves, M.F.; Rocas, I.N.; Siqueira, J.F., Jr. Cleaning, Shaping, and Disinfecting Abilities of 2 Instrument Systems as Evaluated by a Correlative Micro-computed Tomographic and Histobacteriologic Approach. J. Endod. 2020, 46, 846-856. [CrossRef]

45. Walton, R.E. Histological evaluation of different methods of enlarging the pulp canal space. J. Endod. 1976, 2, 304-311. [CrossRef]

46. Siqueira, J.F., Jr.; Araújo, M.C.; Garcia, P.F.; Fraga, R.C.; Dantas, C.J. Histological evaluation of the effectiveness of five instrumentation techniques for cleaning the apical third of root canals. J. Endod. 1997, 23, 499-502. [CrossRef] 
47. Cunningham, W.T.; Martin, H.; Forrest, W.R. Evaluation of root canal debridement by the endosonic ultrasonic synergetic system. Oral Surg. Oral Med. Oral Pathol. 1982, 53, 401-404. [CrossRef]

48. Cunningham, W.T.; Martin, H. A scanning electron microscope evaluation of the root canal debridement with endosonic ultrasonic synergistic system. Oral Surg. Oral Med. Oral Pathol. 1982, 53, 527-531. [CrossRef]

49. De Carvalho, C.M.; Junior, E.C.S.; Garrido, A.D.; Lia, R.C.C.; Garcia, L.F.R.; Marques, A.A.F. Apical Transportation, Centering Ability, and Cleaning Effectiveness of Reciprocating Single-file System Associated with Different Glide Path Techniques. J. Endod. 2015, 41, 2045-2049. [CrossRef]

50. Khalap, N.D.; Kokate, S.; Hegde, V. Ultrasonic versus sonic activation of the final irrigant in root canals instrumented with rotary/reciprocating files: An in-vitro scanning electron microscopy analysis. J. Conserv. Dent. 2016, 19, 368-372. [CrossRef]

51. Lacerda, M.F.L.S.; Marcelino-Alves, M.F.; Perez, A.R.; Provenzo, J.C.; Neves, M.A.S.; Pires, F.R.; Goncalves, L.S.; Rôças, I.N.; Siqueira, F.J., Jr. Cleaning and shaping oval canals with 3 instrumentation systems: A correlative Micro- computed tomographic and histological study. J. Endod. 2017, 43, 1878-1884. [CrossRef]

52. Morales, M.N.P.; Sánchez, J.A.G.; Olivieri, J.G.; Elmsmari, F.; Salmon, P.; Jaramillo, D.E.; Duran-Sindreu, F. Micro-computed Tomographic Assessment and Comparative Study of the Shaping Ability in Six NiTi files-An In Vitro Study. J. Endod. 2021, 47, 812-819. [CrossRef] [PubMed]

53. Conde, A.J.; Estevez, R.; Loroño, G.; de Pablo, O.V.; Rossi-Fedele, G.; Cisneros, R. Effect of sonic and ultrasonic activation on the organic tissue dissolution from simulated grooves in the root canals using sodium hypochlorite and EDTA. Int. Endod. J. 2017, 50, 976-982. [CrossRef] [PubMed]

54. Taneja, S.; Mishra, N.; Malik, S. Comparative evaluation of human pulp tissue dissolution by different concentrations of chlorine dioxide, calcium hypochlorite and sodium hypochlorite: An in vitro study. J. Conserv. Dent. 2014, 17, 541-545. [CrossRef] [PubMed]

55. Hasselgren, G.; Olsson, B.; Cvek, M. Effects of calcium hydroxide and sodium hypochlorite on the dissolution of necrotic porcine muscle tissue. J. Endod. 1988, 14, 125-127. [CrossRef]

56. Moorer, W.R.; Wesselink, P.R. Factor promoting the tissue dissolving capability of sodium hypochlorite. Int. Endod. J. 1982, 15, 187-196. [CrossRef]

57. Gazzaneo, I.; Vieira, G.C.S.; Perez, A.R.; Alves, F.R.F.; Gonçalves, L.S.; MdalaI, I.; Siqueira, J.F.; Rocas, I.N. Root canal disinfection by single- and multiple-instrument systems: Effects of sodium hypochlorite volume, concentration, and retention time. J. Endod. 2019, 45, 736-741. [CrossRef]

58. Guarts, R.; Nusstein, J.; Reader, A.; Beck, M. In vivo debridement efficacy of ultrasonic irrigation following hand-rotary instrumentation in human mandibular molars. J. Endod. 2005, 31, 166-170. [CrossRef]

59. Varela, P.; Souza, E.; de Deus, G.; Duran-Sindreu, F.; Mercadé, M. Effectiveness of complementary irrigation routines in debriding pulp tissue from root canals instrumented with a single reciprocating file. Int. Endod. J. 2019, 52, 475-483. [CrossRef] [PubMed]

60. Castelo-Baz, P.; Varela-Patiño, P.; Cantatore, G.; Domínguez-Perez, A.; Ruíz-Piñón, M.; Miguens-vila, R.; Marti-Biedma, B. In vitro comparison of passive and continuous ultrasonic irrigation in curved root canals. J. Clin. Exp. Dent. 2016, 4, 437-441.

61. Schoeffel, G.J. The EndoVac method of endodontic irrigation, part 3: System components and their interaction. Dent. Today 2008, $27,8-11$.

62. De Gregorio, C.; Estevez, R.; Cisneros, R.; Paranjpe, A.; Cohenca, N. Efficacy of different irrigation and activation systems on the penetration of sodium hypochlorite into simulate lateral canals and up to working length. An in vitro Study. J. Endod. 2010, 7, 1216-1221. [CrossRef] [PubMed]

63. Haapasalo, M.; Wang, Z.; Shen, Y.; Curtis, A.; Patel, P.; Khakpour, M. Tissue dissolution by a novel multisonic ultra-cleaning system and sodium hypochlorite. J. Endod. 2014, 40, 1178-1181. [CrossRef]

64. Budris, A.; Mayleben, P.A. Effects of entrained air, NPSH margin, and suction piping on cavitation in centrifugal pumps. In Proceedings of the 15th International Pump Users Symposium, Houston, TX, USA, 3-5 March 1998; Turbomachinery Laboratory: College Station, TX, USA, 1998; pp. 99-108.

65. Haapasalo, M.; Ørstavik, D. In-vitro infection and disinfection of dentinal tubules. J. Dent. Res. 1987, 66, 1375-1379. [CrossRef] [PubMed]

66. Siqueira, J.F., Jr.; Rôças, I.N. Clinical implications and microbiology of bacterial persistence after treatment procedures. J. Endod. 2008, 34, 1291-1301. [CrossRef] [PubMed]

67. Vieira, A.R.; Siqueira, J.F., Jr.; Ricucci, D.; Weber, S.P.; Lopes, W.S. Dentinal tubule infection as the cause of recurrent disease and late endodontic treatment failure: A Case Report. J. Endod. 2012, 38, 250-254. [CrossRef] [PubMed]

68. Caputa, P.E.; Tesas, A.; Kuijk, L.; de Paz, L.E.C.; Boutsioukis, C. Ultrasonic irrigant activation during root canal treatment: A systematic review. J. Endod. 2019, 45, 31-44. [CrossRef] 